\title{
イオンビーム照射下の熱疲労き裂進展実験と 非線形破壊力学評価
}

\author{
矢川 元 基* 吉 村 忍** 菱 田 博 俊***
}

Experiments and Nonlinear Fracture Mechanics Analyses on

Thermal Fatigue Crack Growth Under

Hydrogen Ion Beam Irradiation

by

\section{Genki YagawA*, Shinobu Yoshimura** and Hirotoshi HishidA***}

This paper is concerned with experiments as well as numerical analyses on thermal fatigue crack growth of Type 304 stainless steel, which is one of candidate materials for the first wall of fusion reactors, under hydrogen ion $\left(\mathrm{H}^{+}\right)$beam irradiation.

In the experiments, a surface-cracked plate specimen set in a vacuum chamber of $10^{-6}$ torr was irradiated repeatedly with $25 \mathrm{keV} \mathrm{H}^{+}$beam pulse of normal distribution, whose peak value and time duration were about $2 \mathrm{MW} / \mathrm{m}^{2}$ and $1 \mathrm{sec}$ in every $45 \mathrm{sec}$, respectively. During the irradiation, temperature on the specimen surface reached $800 \sim 900$ degree C. After several hundreds of irradiation cy. cles, the specimen was cooled down and broken along a cracked plane. Crack growth of about $1 \mathrm{~mm}$ was observed on the fracture surface.

To evaluate such a fatigue crack growth behavior, nonlinear fracture mechanics analyses were performed based on the three-dimensional thermal conduction and thermal elasto-plastic finite element analyses. The temperature dependence of material properties was taken into account. The nonlinear fracture mechanics parameter adopted here was the $\Delta \hat{J}$-integral considering thermal effects.

The crack extension amount $\Delta a$ was estimated using the calculated $\Delta \hat{J}$ value and several experimental data on fatigue crack growth in literature. It is shown that the present estimation scheme can predict the fatigue crack growth phenomena under ion beam irradiation with an accuracy of a factor 4, in spite of the FEM analyses ignoring micro damage effects of irradiation.

Key words : Fusion first wall, Thermal fatigue crack growth, Hydrogen ion beam, Type 304 stainless steel, $\hat{J}$-integral

\section{1 緒言}

磁気閉込め方式核融合炉の第一壁は，プラズマに直 面して扔り，高熱・照射・電磁力などの苛酷な環境下 にさらされる．このため熱疲労，クリープ，衝撃電磁 力, 照射損傷などの種々の破壊要因が懸念されている. なかでもトカマク炉の第一壁では, プラズマ立上げ時 やプラズマ・ディスラプション時に発生する衝撃的な 熱負荷を数年の寿命中にそれぞれ数万回および数百回 程度受けると想定されており，その際の低サイクル熱 疲労現象が第一壁の寿命, ひいては炬全体の寿命を左 右する重大な要因の一つと考えられている.

第一壁の熱疲労現象の特徵としては，粒子線による 表面熱負荷や体積熱負荷に起因して, 通常の熱流体と の接触による熱過渡現象と比べて温度変化が数ミリ秒
から数秒と格段に速いことや，真空中で粒子線による 表面の損傷や不純物の混入を伴うこどなどが挙げられ る.これまでに，オーステナイト系の $304 ， 316$ ステ ンレス鋼やフェライト系の HT9 鋼などの第一壁候補 材料に対して，熱疲労・熱過渡強度に関するさまざま な研究が行われてきた。 たとえば，未照射材や中性子 照射材について，機械的あるでいは熱的な繰返し負荷に よる疲労試験が行われてきた。一方，電子ビームやイ オンビームを用いて，プラズマ・ディスラプション時 の立上がりの速い熱負荷を模擬した照射実験が行われ， 第一壁材料の溶融・凝固挙動の評価や,9 , 罗数の微小き 裂を含む再凝固材の強度評価などが行われている。さ らに,このようなデータをもとに第一壁の寿命評価も 試みられている。しかしながら, 従来の疲労強度デー

$\dagger$ 原稿受理 平成 2 年 2 月 9 日 Received Feb. 9, 1990

* 正会員 東京大学工学部 東京都文京区本郷, Faculty of Engineering, University of Tokyo, Hongo, Bunkyo-ku, Tokyo

** 東京大学工学部 東京都文京区本郷, Faculty of Engineering, University of Tokyo; Hongo, Bunkyo-ku, Tokyo

*** 東京大学大学院 東京都文京区本郷, Graduate Student, University of Tokyo, Hongo, Bunkyo-ku, Tokyo 
夕は必ずしも第一壁環境を十分に模擬したものではな く，より精度の高い第一壁寿命評価を行うためにも， 粒子ビーム負荷に伴う熱疲労現象に関するデー夕の蓄 積と, その評価手法の確立が望まれている.

そこで, 本研究では粒子ビームの熱疲労現象に与え る影響の評価を目的として，パルス状水素イオンビー ムを 304 ステンレス鋼製表面き裂付き平板試験片に繰 返し照射し，き裂進展挙動を実験的に調べた。 その際， 粒子ビーム照射条件下の温度履歴, ひずみ, 変位など のオンライン測定を行った. また，これらの実験に対 して, $\hat{J}$ 積分を破壊力学パラメータとする有限要素法 による熱弾塑性破壊力学解析を行った. その結果得ら れた $\hat{J}$ 積分幅 $\Delta \hat{J}$ と，機械的あるいは熱的負荷を用 いて得られている従来の疲労き裂進展則を用いてき裂 進展量の推定を行い, 上記実験結果と比較した。

\section{2 実験}

\section{$2 \cdot 1$ イオンビーム照射装置}

本研究で使用したイオンビーム照射装置は, 25 $\mathrm{keV}$ の水素イオンビームを発生させることができる. イオンビームは $10^{-6}$ Torr の高真空中で, 水平に固定 された平板試験片に対して，上方から垂直に照射され る.

Fig. 1 に，カロリメータで測定した，試験片固定位 置での水素イオンビームのエネルギ強度分布の一例を 示す. 本ビームの強度分布はピーク值が約 $2 \mathrm{MW} / \mathrm{m}^{2}$ で, 半径約 $10 \mathrm{~cm}$ の軸対称正規分布をしており，商 用核融合炉の第一壁が受ける定常熱負荷のエネルギに ほぼ匹敵する．本装置では，このような強度のイオン ビームの照射時間および照射間隔を, 誤差 $1 \mathrm{msec}$ 程 度の精度であらかじめ設定し, 繰返し発生させること ができる.

\section{$2 \cdot 2$ 供試材および試験片}

供試材は，第一壁候補材料の一つと考えられている， オーステナイト系 304 ステシレス鋼である．供試材の 化学組成を Table Iに示す.

用いた試験片は，Fig. 2 に示され るように板厚 $3 \mathrm{~mm}$, 一辺 $150 \mathrm{~mm}$ の正方形薄板である．試験片は片面 から照射されるが，その照射面中央 部には, 長さ $10 \mathrm{~mm}$, 深さ $1.5 \mathrm{~mm}$ (板厚の半分), スリット幅 $0.1 \mathrm{~mm}$ の矩形表面き裂が放電加工によって 付与されている. 試験片の照射面は シェイパーによって平らに削られて いるのみであり，その他に特別な表 面処理は施されていない.

\section{$2 \cdot 3$ 実験方法}

Fig. 2 に示すように，拘束治具に

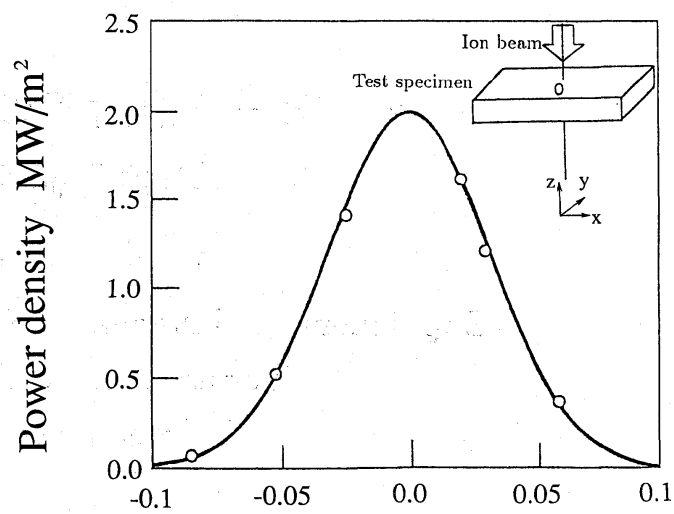

Distance from the center of specimen $\mathrm{m}$

Fig. 1. Power density distribution of ion beam

よって試験片のき裂面と平行な 2 辺を完全に拘束する. 試験片と拘束治具は, $10^{\circ} \mathrm{C}$ の流水で常時泠却されて いる台の上に設置される.このため繰返しイオンビー ム照射を受ける試験片は，照射による加熱過程と水冷 および輻射による冷却過程を通じて圧縮・引張りの繰 返し熱荷重を受ける.

本実験ではイオンビームの照射時間を, 45 秒ごと に 1 秒 $\left(2 \times 10^{-2} \mathrm{~Hz}\right)$ とした。 これは実機の定常熱負荷 の熱サイクルとオーダー的に一致している.

本実験は, イオンビーム照射下の熱疲労き裂進展実 験であるため, 試験中にき裂進展量を測定することが 非常に困難である，そこで，試験片に所定の回数（本 研究では 200 回と 600 回) 照射した後に試験片を室温 まで自然冷却させ, 真空容器から取り出し, 機械的疲 労（両振り $100 \mathrm{~Hz}$ ）により破断し, 倍率 20 倍の光学

Table I. Chemical composition of Type 304 stainless steel.

(Wt\%)

\begin{tabular}{c|c|c|c|c|c|c}
\hline $\mathrm{C}$ & $\mathrm{Si}$ & $\mathrm{Mn}$ & $\mathrm{P}$ & $\mathrm{S}$ & $\mathrm{Ni}$ & $\mathrm{Cr}$ \\
\hline 0.06 & 0.68 & 1.01 & 0.02 & 0.01 & 8.80 & 18.4 \\
\hline
\end{tabular}

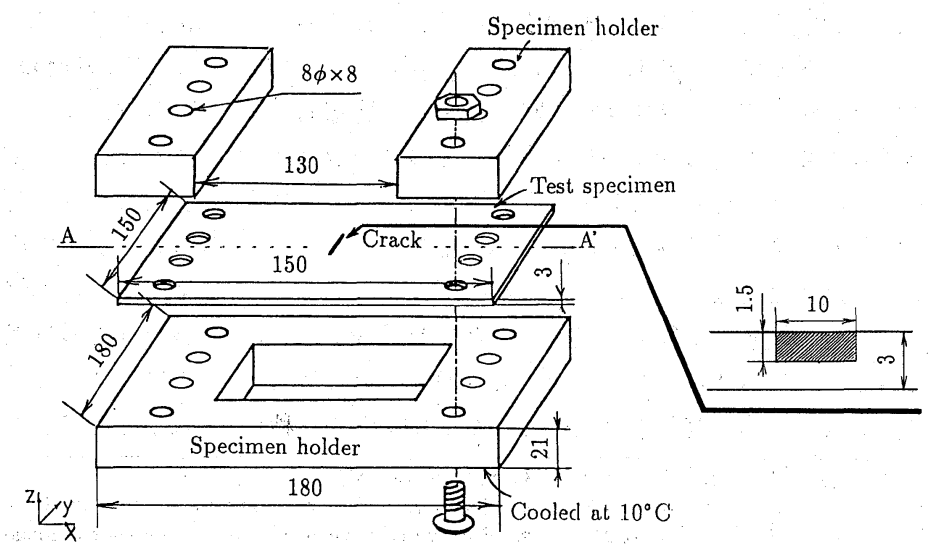

Fig. 2. Configurations of specimen and its holder.

( 52 ) 


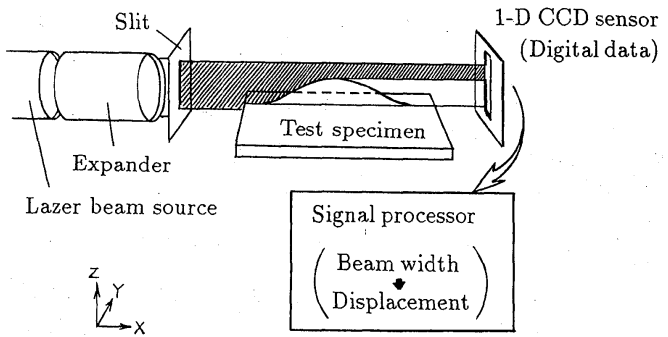

Fig. 3. Principle of displacement transducer by means of lazer beam.

顕微鏡を用いてき裂進展量を測定した。

また照射試験の間，試験片裏面の温度およびひずみ， 試験片中央部の照射方向（Z 方向）変位をそれぞれ 熱電対，抵抗型ひずみゲージおよび著者らが開発した 非接触型レーザ变位計（応答速度 $10 \mathrm{kHz}$ ，最小測定 精度 $0.06 \mathrm{~mm}$ ）を用いてオンライン測定した. Fig. 3 にレーザ変位計の測定原理を示す．エキスパンダで拡 大されスリットを通して平行光線となったレーザビー ムは，試験片の変形に伴いその一部を遮断される。 そ こで試験片を狭むように設置された受光素子まで到達 するレーザビームの幅の変化を電気的に測定すること によって，試験片の Z 方向変位が測定される．なお， 本装置では受光素子に一次元 CCD センサを用いてデ ジタル的に測定しており，イオンビームや外部の光学 的条件に依らず安定した測定ができるようになってい る.

以上の測定結果は， 3 章に述べる数值解析の精度を 検証する際に参照される.

\section{$2 \cdot 4$ 実験結果}

Fig. 4 に，実験から得られた試験片裏面中央部の温 度履歴を模式的に示す。試験片温度は, 幅約 $85^{\circ} \mathrm{C}$ の 変動を繰り返しながら室温から徐々に上昇し, 照射繰 返し数が約 50 回で平均約 $520^{\circ} \mathrm{C}$ の定常に到達する.

照射回数 200 回および 600 回の実験に対して得られ た破面の模式図を Fig. 5 に示す．長手方向へのき裂進

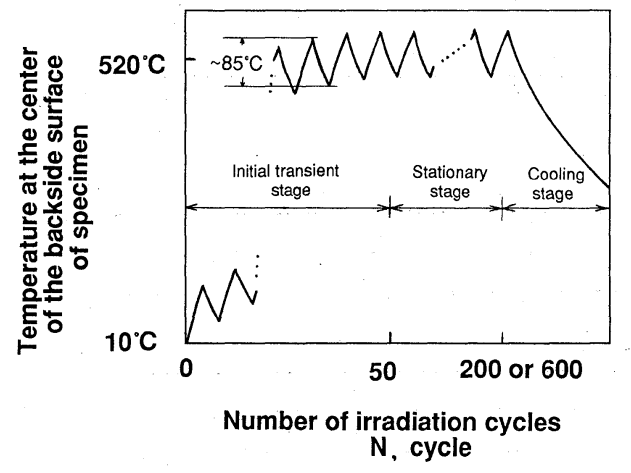

Fig. 4. Schematic time history of temperature at the center of backside surface of specimen.

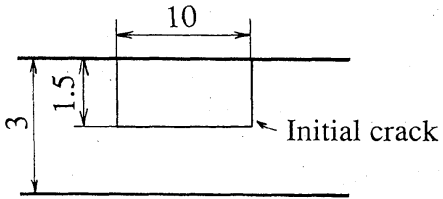

(a) $\mathrm{N}=0$ cycle

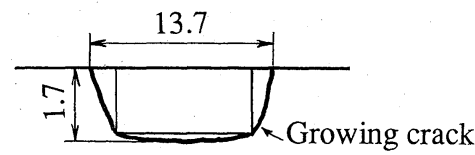

(b) $\mathrm{N}=200$ cycles

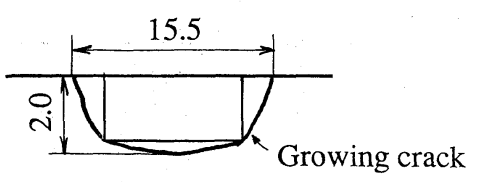

(c) $\mathrm{N}=600$ cycles

Fig. 5. Schematic views of fracture surfaces.

展が深さ方向へのき裂進展量よりはるかに顕著である こと, また, 深さ方向への進展量の分布はき裂前縁に 沿ってかなり緩やかであることが確認される.

次節以降では，この実験に対して非線形有限要素法 解析に基づく評価を行い，き裂進展量を予測し，この 結果との比較を行う。

\section{3 解 析}

2 章で述べた実験体系の複雑な非線形・非定常応答 を評価するために，非線形有限要素解析コード FINAS $\stackrel{16}{S}$ 用いて非定常熱伝導解析, 熱弾塑性破壊力 学解析を順次行い, 実験結果との比較を行った。

なお, 本解析では, 現象の第一次近似として, 一般 的な非定常熱弾塑性モデルに基づく評価を目的とした ので，粒子のミクロな注入効果やき裂面からの熱の流 入・流出, 詳細な繰返し塑性効果などについては考慮 しなかった。

\section{$3 \cdot 1$ 熱伝導解析}

まず, 3 次元非定常熱伝導解析を行い, 試験片内の 温度分布を計算した. Fig. 6 に解析に用いた要素分割 (4 分の 1 モデル : 20 節点アイソパラメトリック要素, 1133 要素, 1947 節点) を示す. 試験片・拘束治具・ 支持台は熱的に完全に密着しているものとし，イオン ビームからの入熱（Fig. 1 の熱流束が $100 \%$ の効率で 表面熱負荷で与えられると仮定), 試験片や拘束治具 の表面からの輻射 $\left(20^{\circ} \mathrm{C}\right.$ 雲囲気への輻射を仮定), 冷 水による支持台の冷却効果（流水と支持台の接触面は $10^{\circ} \mathrm{C}$ で一定）を考慮した。ここでは，試験片が $10^{\circ} \mathrm{C}$ の初期状態から Fig. 4 の繰返し入熱によって温度が上 


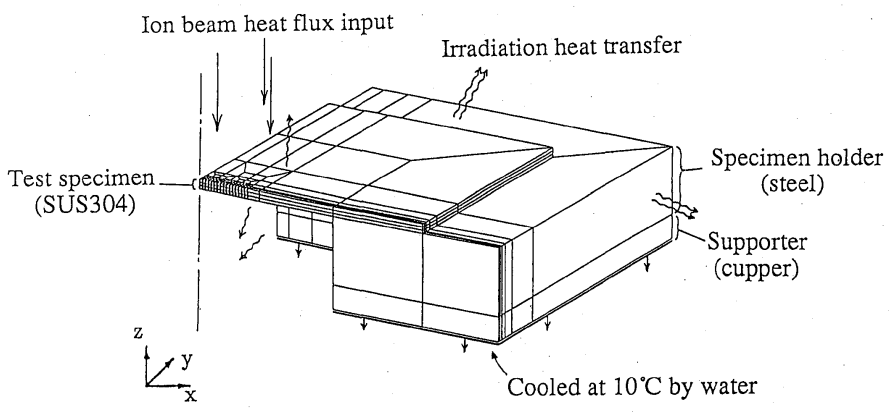

Fig. 6. Three dimensional mesh subdivision used in thermal conduction analysis.

Table II. Material properties used in the thermal conduction analysis

\begin{tabular}{c|c|c|c}
\hline $\begin{array}{c}\text { Temperature } \\
{ }^{\circ} \mathrm{C}\end{array}$ & $\begin{array}{c}\text { Thermal } \\
\text { conductivity } \\
\mathrm{J} / \mathrm{m} \mathrm{sec} \mathrm{K}\end{array}$ & $\begin{array}{c}\text { Thermal } \\
\text { diffusivity } \\
\mathrm{m}^{2} / \mathrm{sec}\end{array}$ & $\begin{array}{c}\text { Specific heat } \\
\mathrm{J} / \mathrm{kg} \mathrm{K}\end{array}$ \\
\hline 0 & 14.3 & $3.76 \times 10^{6}$ & 443 \\
200 & 17.0 & 4.05 & 525 \\
400 & 19.7 & 4.56 & 554 \\
600 & 22.4 & 4.87 & 579 \\
800 & 25.2 & 5.25 & 613 \\
1000 & 28.0 & 5.63 & 647 \\
\hline
\end{tabular}

昇し，ほぼ定常に達する 50 サイクル目までを解析し た。なお，本解析には Table II に示される温度依存 性を考慮した物性値を使用した。

Fig. 7 に 50 サイクル目の試験片裏面の 3 点におけ る温度履歴を示す。実線が解析結果, 破線が熱電対に よる測定結果である。いずれも解析值と測定值との間 に良好な一致が見られるが，このように両者がよく一 致した理由としては，本実験体系では入熱量や冷却条 件をかなり精度よく把握できているためと考えられる。 この解析より，照射面およびき裂先端近傍の温度はそ れぞれ $900^{\circ} \mathrm{C}$ および $700^{\circ} \mathrm{C}$ 程度に達していること， また，き裂先端近傍でのき裂の長手方向の温度勾配は， 深さ方向のそれよりも十分に小さ いことなどが分かった.

\section{$3 \cdot 2$ 熱弾塑性解析}

本実験体系は 3 次元的であるが, そのまま 3 次元の表面き裂に対し て熱弾塑性解析を行うと非常に膨 大な計算量となる。本問題の場合, 予き裂がへん平な矩形形状で深さ 方向へのき裂進展も Fig. 5 に見ら れたように比較的分布が緩やかで あること，およびき裂周辺の温度 分布もき裂長手方向にはほとんど 勾配を持たないことから，き裂深 さ方向のき裂進展現象は 2 次元近 似がしやすいと考えられる。そ己
で Fig. 2 に示されるき裂最深部を含む $\mathrm{A}-\mathrm{A}^{\prime}$ 断面に対して 2 次元の平面ひず み熱弾塑性解析を行った. Fig. 8 に, 用いた要素分割（2 分の 1 のモデル： 8 節点アイソパラメトリック要素, 98 要素, 306 節点) を示す. 解析で は，Mises の降伏条件と等方硬化則 を仮定し，物性値としては Table III に示される温度依存性を考慮したもの を用いた. なお, 解析ではイオンビー ムの試験片内部やき裂内部への侵入効 果は考慮しなかった。

解析では $3 \cdot 1$ 節で述べた熱伝導解析から得られた 50 サイクル目の各節点の温度履歴を入力データとし て使用し，50 サイクル目の 1 サイクルについて計算 を行った。き裂深さが $1.5 \mathrm{~mm}$ および $2.0 \mathrm{~mm}$ の 2 つ

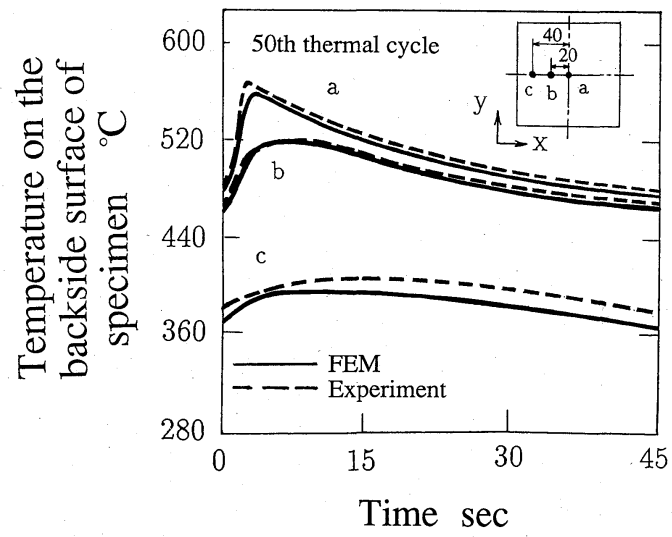

Fig. 7. Time history of temperature on the backside surface of specimen during 50 th thermal cycle.

(Comparison between numerical and experimental results).

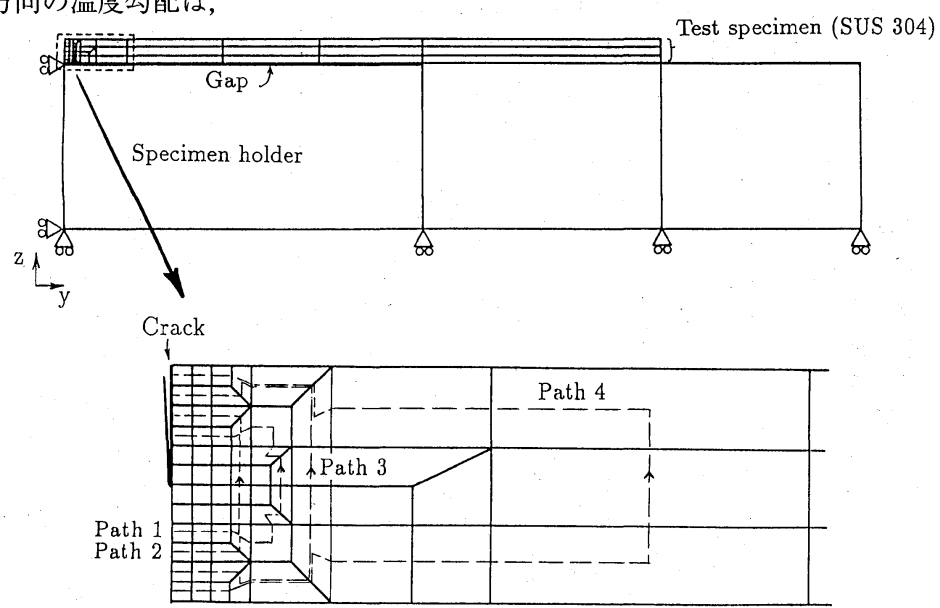

Fig. 8. Two dimensional mesh subdivision and $J$-integral paths used in thermal elasto-plastic analysis. 
Table III. Material properties used in the thermal elastoplastic analysis.

\begin{tabular}{c|c|c|c|c|c|c}
\hline $\begin{array}{c}\text { Temperature } \\
{ }^{\circ} \mathrm{C}\end{array}$ & $\begin{array}{c}\text { Young's modulus } \\
\mathrm{MN} / \mathrm{m}^{2}\end{array}$ & Poisson's ratio & $\begin{array}{c}\text { Mass density } \\
\mathrm{kg} / \mathrm{m}^{3}\end{array}$ & $\begin{array}{c}\text { Thermal expansion rate } \\
1 / \mathrm{K}\end{array}$ & $\begin{array}{c}\text { Yield stress } \\
\mathrm{MN} / \mathrm{m}^{2}\end{array}$ & $\begin{array}{c}\text { Hardening ratio } \\
\mathrm{MN} / \mathrm{m}^{2}\end{array}$ \\
\hline 0 & $1.95 \times 10^{5}$ & 0.262 & $8.04 \times 10^{3}$ & $1.63 \times 10^{-5}$ & 155 & $10.77 \times 10^{3}$ \\
200 & 1.85 & 0.280 & 7.95 & 1.73 & 143 & 9.53 \\
400 & 1.69 & 0.295 & 7.86 & 1.80 & 131 & 8.29 \\
600 & 1.49 & 0.309 & 7.76 & 1.87 & 92 & 7.14 \\
800 & 1.29 & 0.325 & 7.68 & 1.91 & 72 & 5.59 \\
1000 & 1.09 & 0.341 & 7.60 & 1.95 & 4.35 & 72 \\
\hline
\end{tabular}

の停留き裂について解析を行い, き裂進展を模擬した. なお，変形の際にき裂面の接触が予想されるため，き 裂面の節点に変位が負になると大きな反力が発生する ようなばね定数を与えた。

Fig. 9 にき裂長さ $1.5 \mathrm{~mm}$ の場合の試験片中央部の 照射方向 ( $\mathrm{Z}$ 方向) 変位の時間履歴を示す. ここで 実線が解析結果を, 破線がレーザー変位計による測定 結果を示す. また，Fig. 10 に試験片裏面の 2 点にお けるひずみの時間履歴の解析結果 (実線) と実験結果 （破線）との比較を示す．而図より，変位もひずみも 解析結果が実験結果よりやや大き目の結果となってい るものの比較的良好に一致しており, 本解析が 2 次元 解析ながら試験片中央部の熱弾塑性変形現象をかなり 正確に再現していると考えることができる，なお，解 析結果がやや高くなる理由としては, 実際の温度は中 央部をピークとする分布をとるのに対して，解析では ピーク值に基づいて 2 次元解析を行っているためと考 えられる。

紙面の都合上，図には示さないが，き裂先端近傍の 垂直応力 $\sigma_{\mathrm{yy}}$ は照射直後は全般的に圧縮となるものの, 時間とともに急速に引張りに近づく。その減少のス

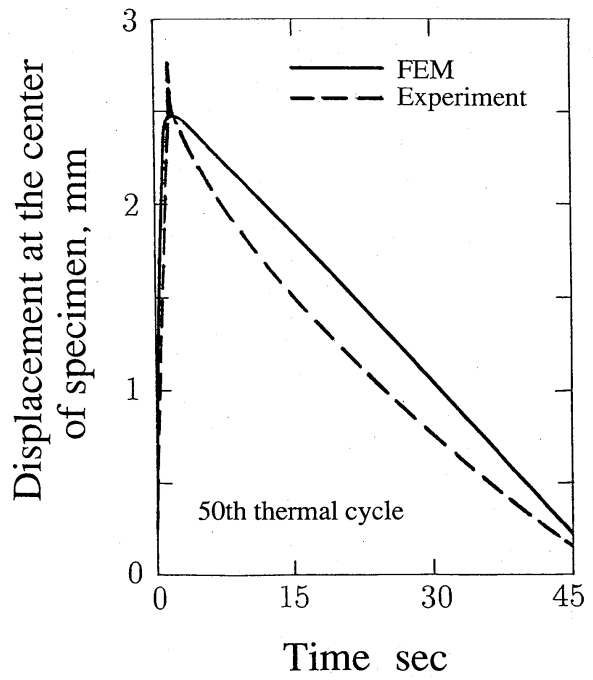

Fig. 9. Time history of displacement at the center of specimen in the $Z$ direction.

(Comparison between numerical and experimental results).

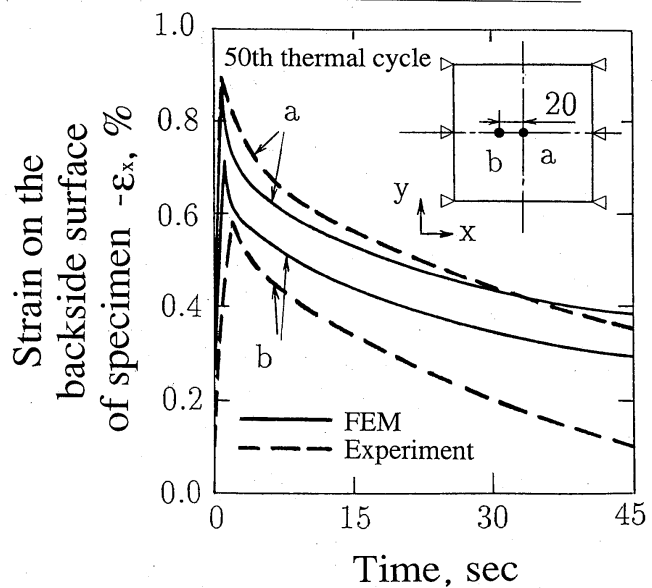

Fig. 10. Time histories of strains on the backside surface of specimen.

(Comparison between numerical and experimental results)

ピードは照射表面に近いほど速い，また，き裂先端近 傍のひずみ速度は約 $0.1 \% / \mathrm{sec}$ のオーダーであり， クリープの効果はほとんどないことも予想される.

\section{$3 \cdot 3 \hat{\boldsymbol{J}}$ 積分の計算}

本実験は急激な温度変化を伴う非線形な熱疲労き裂 進展現象を対象とするので, $3 \cdot 2$ 節の計算結果をも とに, 破壊力学パラメータとして次式の $\hat{J}$ 積分の履 歴を計算した。

$$
\hat{J}=-\int_{\Gamma} T_{i} \frac{\partial u_{i}}{\partial \chi_{1}} d \stackrel{\oplus}{+}+\iint_{A} \sigma_{i j} \frac{\partial \varepsilon_{i j}}{\partial \chi_{1}} d A
$$

ここで， $T_{i}$ は経路 $\Gamma$ 上に作用する表面力， $u_{i}$ は変位, $\mathrm{A}$ は経路 $\Gamma$ の囲む領域， $\sigma_{i j}$ は応力， $\varepsilon_{i j}$ は熱ひずみ を含む全ひずみをそれぞれ表わす， $\mathrm{J}$ 積分の計算には Fig. 8 に示す 4 つの経路を用いた.

Fig. 11 に各経路で計算された照射後 15 秒および 45 秒経過したときの $\hat{J}$ 積分の值を示す. 経路長さに比 べて要素分割が不十分な最内側の経路 1 の結果を除い て, 他の 3 経路の值は良好な経路独立性を示している。

Fig. 12 に外側 3 経路の値を平均して得られた $\hat{J}$ 積 分の時間履歴を示す。ここには予き裂が $1.5 \mathrm{~mm}$ 拉よ び $2.0 \mathrm{~mm}$ の結果を示す.いずれの場合も $\hat{J}$ 積分の値 は初め負の值をとるが, 照射開始後 10 秒程度経過し たあたりから正に転じ，そのまま次第に増加すること 


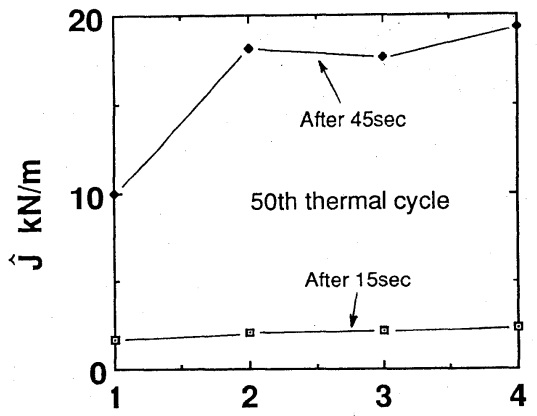

Path No.

Fig. 11. Independence of $\hat{J}$ integral.

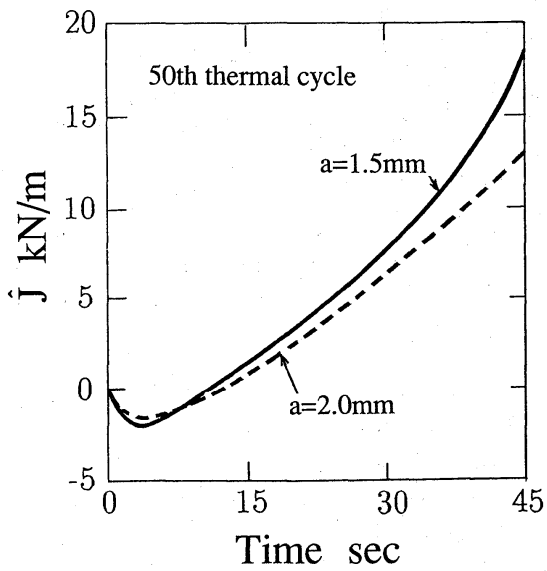

Fig. 12. Calculated time history of $J$ integral for two different crack lengths.

が分かる. 同図において $\hat{J}$ 積分值が負の值をとる初 めのうちはき裂面が閉じ接触していると予想されるが,

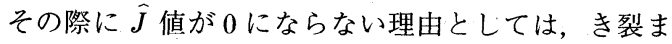
わりに生じる複雑な圧縮熱応力の効果によるものと考 えられる.

\section{$4 \cdot 1$ き裂進展則}

\section{4 き裂進展の予測}

一般に疲労き裂進展は, 応力拡大係数幅 $\Delta K$ ある いは $J$ 積分幅 $\Delta J$ を用いて，次のように整理される.

$$
\begin{aligned}
& \frac{d a}{d N}=C(\Delta K)^{m} \\
& \frac{d a}{d N}=C^{\prime}(\Delta J)^{m^{\prime}}
\end{aligned}
$$

ここで， $a$ はき裂長さ， $N$ は負荷の繰返し数， C, $m$ および $C^{\prime}, m^{\prime}$ は材料定数である. 式 (3) は荷重レべ ルが高く塑性の効果が無視できない場合に利用され る.

本研究では, 従来の実験研究から得られている疲労 き裂進展に関するデー夕と, Fig. 12 から得られる $\hat{J}$ 積分幅 $\Delta \hat{J}$ を用いて, 本実験から得られたき裂進展量 を予測することを試みた. $\Delta \hat{J}$ の算出法としては，き
裂開口の時点からの $\hat{J}$ の増分が 1 サイクルのき裂進 展現象を最も反映しているという久保らの研究がある が，ここでは最も単純な仮定として Fig. 12 における $\hat{J}=0$ のときをき裂開口点とし 0 から正の最大值まで の $\hat{J}$ 積分の変動幅を $\Delta \hat{J}$ と定義し, き裂進展の評価 に用いた.なお， $\Delta \hat{J}$ を最小值から最大值までとして も 1 割程度増加するだけである.

\section{$4 \cdot 2 \Delta \hat{\boldsymbol{J}}$ 評価上の注意事項}

$\Delta \hat{J}$ はさまざまな因子に依存するが, 本実験の評価 の際には，少なくともき裂長さ $a$ の変化と照射初期 の温度変動の遷移挙動を考慮する必要があると考えら れる.

そこで, $\Delta \hat{J}$ と $a$ との関係としては, 最も単純に $a$ $=1.5 \mathrm{~mm}$ から $2.0 \mathrm{~mm}$ の間で線形であると仮定し,

Fig. 12 に示される $a=1.5 \mathrm{~mm}$ と $2.0 \mathrm{~mm}$ の解析結果 から任意の $a$ の值に対して $\Delta \hat{J}$ を評価できるように した. また， $\Delta \hat{J}$ と温度変動幅 $\Delta T$ との関係について は, (1) $\Delta \hat{J}$ は $\Delta T$ によらず一定である, (2) $\Delta \hat{J}$ は $\Delta T$ と比例する, (3) $\Delta \hat{J}$ は $\Delta T$ の 2 乗に比例する, とい う 3 つの仮定を置いて評価したが，その結果 1 ～ $2 \%$ 程度の差しか生じないことが分かった。 そこで，200 ないし 600 回の照射実験中, 温度変動幅は一定である と仮定した.

\section{$4 \cdot 3$ き裂進展量の推定}

上述の $\Delta \hat{J}$ と従来の実験から得られている種々のき 裂進展則を用いて, 本実験における深さ方向のき裂進 展量の予測を行った. すなわち, 式(3)を積分した

$$
a=C^{\prime} \int_{0}^{N}(\Delta \hat{J})^{m^{\prime}} d N
$$

の式に, 従来の実験から得られている $C^{\prime}$ や $m^{\prime}$ の值 （ただし $J$ 値と $K$ 值との関係を使って $C$ や $m$ の值か ら換算した）を代入し，4・2節で述べた方法によっ てき裂進展を考慮して評価した $\Delta \hat{J}$ を代入することに より，き裂進展量を予測した。

この結果を Fig. 13 に示す.ここで, 白丸印は桑原

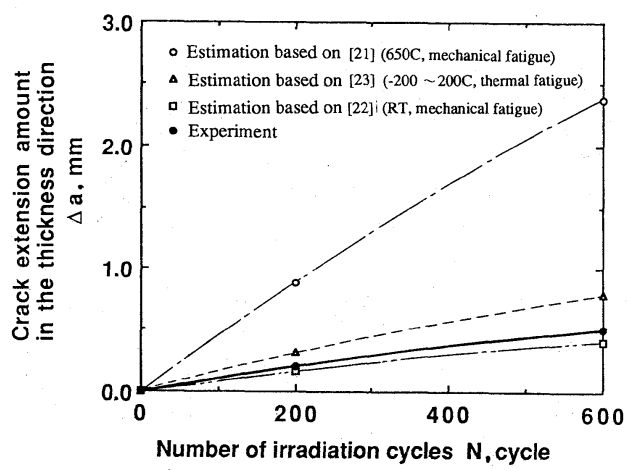

Fig. 13. Comparison between experimental and predicted crack growths. 
らの雲囲気温度 $650^{\circ} \mathrm{C}$ で低サイクルの機械疲労に よって得られた 304 ステンレス鋼のき裂進展則（ $C^{\prime}$ $\left.=0.0736, m^{\prime}=1.43\right)^{21)}$ を用いて予測した結果, 白四角 印は Tobler らの室温での低サイクルの機械疲労に よって得られた 304 ステンレス鋼のき裂進展則（ $C^{\prime}$ $\left.=0.0028, m^{\prime}=1.73\right)^{22)}$ を用いて予測した結果である.

また，白三角印は 316 ステンレス鋼のデータであるが, 岡本らの低サイクル熱衝撃疲労（温度変動幅: -200 $\left.\sim 200^{\circ} \mathrm{C}\right)$ によって得られたき裂進展則 $\left(C^{\prime}=0.0031\right.$, $\left.m^{\prime}=2.19\right)^{23)}$ を用いて予測した結果であり, 黑丸印は 実験から得られた深さ方向へのき裂進展量を示す。

同図によると, 本実験と温度条件が近い高温雾囲気 中の機械疲労試験結果を用いる場合が最も過大な予測 結果を与える一方で，他の 2 つのデータを用いた予測 結果とはよく一致していることがわかる. 本解析で は $\hat{J}$ 積分を 2 次元で解析しているので, $3 \cdot 2$ 節で述 ベたように $\Delta \hat{J}$ を実際の值より過大に評価している恐 れがある.しかし，たとえ $\hat{J}$ 積分の結果が 2 割程度 変化したとしても, き裂進展の予測結果は $4 \sim 5$ 割変 化する程度であり, Fig. 13 の基本的な傾向は変わら ないものと考えられる。むしろ，この図からは，本論 文で示した FEM に基つく予測手法が材料のミクロな 損傷の影響を考慮していない近似的なものであるにも かかわらず, イオンビーム照射下の熱疲労き裂進展挙 動をファク夕 4 程度の精度で予測できることが分かる この主な原因としては，イオンビーム照射によるミク 口な材料損傷より, 従来型の熱応力による疲労き裂進 展挙動が支配的であることと，本体系では従来の流体 を利用する熱疲労実験と比べて，熱的境界条件がかな り明確に把握できるためと考えられる.

また，一般に同じ環境下の疲労き裂進展実験であっ ても，き裂進展データの $C^{\prime} や m^{\prime}$ の值がかなりばら つき，これが予測精度に大きな影響を与えることが懸 念される.しかし，この点については，本実験におけ るき裂進展速度は $10^{-3} \mathrm{~mm} /$ 回程度とかなり大きく, 比較的データがばらつかない領域であったことも，本 研究において実験結果と予測值とがよく一致した一つ の要因と考えられる.

\section{5 結訔}

304 ステンレス鋼製の矩形表面き裂付き平板試験片 に対して，水素イオンビームを用いた熱疲労き裂進展 試験を行い，き裂進展挙動を観測した。 また非定常熱 伝導および熱弾塑性有限要素解析を行い, 破壊力学パ ラメータ $\hat{J}$ を用いてこの挙動を評価した. その結果, $\Delta \hat{J}$ の解析結果と, 従来求められているさまざまなき 裂進展則を用いることにより, 解析において照射の効 果を無視しても, ファクタ 4 程度の精度でイオンビー 么照射下の熱疲労き裂進展を予測できることが分かっ
た.

本研究に用いた FINAS コードは動燃事業団より東 大大型計算機センターにライブラリ登録されたもので, その使用に際して (株) CRCにご協力をいただいた。 こに感謝の意を表する. 最後に, 本研究は昭和 63 年 度文部省科学研究費「核融合特別研究」の一部として なされた研究の成果をまとめたものであることを付記 し，謝意を表する.

（平成元年 9 月 27 日 第 5 回破壊力学シンポジウムにて講演）

\section{参 考 文 献}

1 ) 矢川元基, 核融合研究, $5 \mathbf{5 6}, 248$ (1986).

2 ）核融合炬構造設計基準に関する調查研究分科会成果報告 書, 日本機械学会, P-SC80, No.361, 14 (1987).

3 ) M. A. Leontorich (Edited), Review of Plasma Physics, 5, 349 (1970).

4 ) 宮 健三, 関 昌弘, 荒木政則, 日本原子力学会誌, 29, 855 (1987).

5 ) 小寺沢良一, 納所孝至, 材料, 37, 1090 (1988).

6 ) R. O. Ritchie, Int. Mat. Rev., 5-6, 205 (1979).

7 ) L. A. James, At. En. Rev., 14, 37 (1976).

8 ) 大谷隆一, 北村隆行, 多田直哉, 日本機械学会論文集, A -53, 1030 (1987).

9 ) 小川益郎, 関 昌弘, 湊 章男, 深谷 清, 東稔達三, 日本原子力学会誌, 28, 1038 (1986).

10）石野 秝, 日本原子力学会誌, 31, 120 (1989).

11）昭和63年度文部省科学研究費補助金研究成果報告書, 核 融合特別研究第 5 班, p. 1 (1989).

12）小林英男, 荒居善雄, 梶山佳弘, 班目春樹, 日本機械学 会講演論文集, No.89-0377A, 179 (1989).

13) R. D. Watson, R. R. Peterson and W. G. Wolfer, Trans. ASME, J. of Press. Vess. Tech., 105, 144 (1983).

14) R. W. Conn, First Wall and Diverter Plate Material Selection in Fusion Reactors, UWFDM-237 (1978).

15) 岸本喜久雄, 青木 繁, 坂田 勝, 日本機械学会論文集, A -46, 1049 (1980).

16) PNC SN2S2 81-03, FINAS 高速炉非弾性構造解析シ ステム使用説明書, Version 6.1 (1983).

17) N.E. Dowling, ASTM STP 637, 97 (1977).

18）鈴木信行, 中沢 一, 日本機械学会論文集, A-55, 34 (1989).

19）大路清嗣, 小倉敬二, 久保司郎, 日本機械学会論文集, A -42, 350 (1976).

20）久保司郎, 屋富祖建樹, 野原政俊, 大路清嗣, 日本機械 学会論文集, A-55, 134 (1989).

21）桑原和夫, 新田明人, 北村隆行, 材料, 33, 338 (1984).

22) R. L. Tobler and R. P. Reed, Adv. Cryo. Eng., 24, A-Cap. 8, 82 (1978).

23）岡本潤一, 清水真佐男, 日本機械学会論文集, A -52, 672 (1986). 